Jurnal Pengurusan 55(2019) $3-12$

https://doi.org/10.17576/pengurusan-2019-55-01

\title{
Social Support, Pay Satisfaction, Work Ability, and Intention to Stay: A Case of Return to Work Program Participants
}

\author{
(Sokongan Sosial, Kepuasan Bayaran Gaji, Keupayaan Kerja, dan Hasrat untuk Kekal: Satu Kes tentang \\ Peserta Program Kembali Bekerja)
}

\author{
Johanim Johari \\ (School of Business Management, Universiti Utara Malaysia) \\ Fatimah Zailly Ahmad Ramli \\ (School of Applied Psychology, Social Work and Policy, Universiti Utara Malaysia) \\ Harlida Abdul Wahab \\ Muhammad Firdaus Bidin \\ (School of Law, Universiti Utara Malaysia) \\ Roshaimi Mat Rosely \\ (Social Security Organisation, Ministry of Human Resources Malaysia)
}

\begin{abstract}
The main objective of this study is to examine the influence of social support and pay satisfaction on intention to stay among employees who have undergone return to work (RTW) program. Work ability is also assessed as the mediating variable to explain the indirect link between the independent and dependent variables. A survey was conducted among employees across various sectors in the Klang Valley. A total of 187 responses were gathered and data was analyzed using Statistical Package for Social Sciences (SPSS) and Partial Least Square (PLS) 2.0. Based on the statistical analyses, it was found that pay satisfaction was significantly related to work ability of RTW participants but social support did not pose any substantial impact on this outcome. Work ability was also reported to have exerted a significant impact on RTW participants' intention to stay. Furthermore, the result indicated that work ability provided a significant mediating effect on the link between pay satisfaction and intention to stay. Drawing on the findings, discussions highlighted on the plausible reasons why pay satisfaction is crucial in enhancing work ability and in ensuring that RTW participants continue to retain their present employment. Finally, this study also provides important theoretical and practical ramifications for practitioners in developing measures to elevate the intention to stay among RTW participants.
\end{abstract}

Keywords: Social support; pay satisfaction; work ability; intention to stay; return to work

ABSTRAK

Objektif utama kajian ini adalah untuk mengkaji pengaruh sokongan sosial dan kepuasan bayaran gaji ke atas hasrat untuk kekal dalam kalangan pekerja yang pernah menyertai program kembali bekerja. Keupayaan kerja dinilai sebagai faktor perantara untuk menjelaskan tentang hubungan tidak langsung antara pembolehubah tidak bersandar dan pembolehubah bersandar. Kaji selidik dijalankan dalam kalangan peserta program kembali bekerja di pelbagai sektor di Lembah Klang. Sejumlah 187 maklum balas diperolehi dan data dianalisis menggunakan Pakej Statistik untuk Sosial Sains dan “Partial Least Square (PLS) 2.0.” Berdasarkan analisis statistik yang dijalankan, didapati bahawa kepuasan bayaran gaji mempunyai hubungan yang signifikan dengan keupayaan kerja para peserta program kembali bekerja manakala sokongan sosial tidak memberi sebarang impak. Keupayaan kerja juga dilaporkan memberi impak yang signifikan kepada hasrat untuk kekal. Selain itu, hasil kajian menunjukkan bahawa keupayaan kerja memberi kesan perantara yang signifikan ke atas hubungan antara kepuasan bayaran gaji dan hasrat untuk kekal. Berdasarkan hasil dapatan, perbincangan memberikan justifikasi tentang kepentingan kepuasan bayaran gaji dalam meningkatkan keupayaan kerja dan hasrat untuk kekal dalam pekerjaan bagi peserta program kembali bekerja. Akhir sekali, kajian ini juga memberi beberapa implikasi teoretikal dan praktikal yang penting kepada pengamal dalam membentuk langkah-langkah untuk meningkatkan hasrat untuk kekal dalam kalangan peserta program kembali bekerja.

Kata kunci: Sokongan sosial; kepuasan bayaran gaji; keupayaan kerja; hasrat untuk kekal; program kembali bekerja

\section{INTRODUCTION}

Return to Work program (RTW) basically aims to improve the productivity and morale of employees, to save employers' resources, particularly in terms of time and money, to prevent loss of productivity due to employees' absence from work, and also to avoid the loss of skilled workers (EARN 2018). Most importantly, RTW programs are developed in tandem with the organizational strategies, which is to reduce the compensation costs related to employees' disability benefits. In Malaysia, the Social Security Organization (SOCSO) or also known 
as Pertubuhan Keselamatan Sosial (PERKESO) is an entrusted body to be fully in-charge of the RTW program. SOCSO's inclusive model of RTW program involves a proactive approach in engaging and helping workers with occupational injury or diseases to achieve their maximum functional capacity to work. It is recorded that approximately 1,141 participants involved in RTW program between 2014 until June 2015 in the country (SOCSO Report 2015). It is the aim of SOCSO that every RTW participant has an opportunity to engage in safe and productive work activities as soon as it is medically possible or when maximum medical improvement is achieved with a primary focus of minimizing the impact of injuries or disabilities (SOCSO Report 2016).

The success of RTW program is evident as documented in the literature. For instance, a study by Chan et al. (2016) reported that 60 percent of stroke patients returned to work after undergoing six months of health treatment. In the Malaysian context, a study by Awang, Shahabudin and Mansor (2016) indicated that 65 percent of RTW program participants has successfully returned to work. Approximately two-third of injured workers were reemployed, either with the same or different employer (Awang, Shahabudin \& Mansor 2016). It is also reported that the majority of RTW participants, who went back to work in the same organization, would receive roughly the same amount of monthly salaries as per the emolument prior to their injuries (Awang, Mansor \& Rodrigo 2015). A study by Yean, Johari and Sukery (2015) found that attitude and subjective norms have positively influenced intention to return to work among RTW participants while the link between perceived behavioural control and intention to return to work is not substantiated. Nevertheless, despite the effectiveness of the program in ensuring participants' return to work, the level of retention among RTW practicipants in the new employment, particularly in the Malaysian setting, deserves further scrutiny. Furthermore, despite abundance of studies, especially in the Western context that have explored the success factors of RTW program (see for example Ahlstrom et al. 2016; Awang et al. 2016; Jetha et al. 2016; Steenstra et al. 2016), the perspective on this issue from a developing country like Malaysia is still scarce. This calls for more studies in order to elucidate the key factors that may influence the intention to stay among RTW participants in the local context.

Previous studies examined a wide array of predictors related to the effectiveness of RTW programs. Based on the documented empirical evidence, the program effectiveness can be attributed to factors related to characteristics of individual participants (e.g. mindfulness, work ability, and self-efficacy) as well as situational conditions (i.e. related to the context in which an individual is working or living). However, it is worthy to note that the success of RTW is not only determined by the percentage of work returnees. In fact, it is also important to examine the extent to which they will stay in the present employment following recovery from their injuries. Accordingly, this study intends to provide insights on the critical factors related to intention to stay among RTW participants.
In cognizance that success of the RTW program could be dependent on factors related to individuals as well as their environment, this study integrates contextual factors (i.e. pay satisfaction and social support) as the independent variables and person factor (i.e. work ability) as the mediator in understanding the antecedents of intention to stay among RTW participants in Malaysia. Underpinned by Social Exchange Theory and Broaden and Build Theory, the main objective of this study is to examine the influence of pay satisfaction and social support on work ability. Additionally, the role of work ability as a mediator is assessed in the hypothesized link.

\section{LITERATURE REVIEW}

This section commences with the conceptual foundation of intention to stay. This is followed by the conceptual background of social support, pay satisfaction, and work ability. Finally, this section presents the hypotheses and framework of the study.

\section{CONCEPTUAL BACKGROUND OF INTENTION TO STAY}

One salient challenge faced by employers nowadays is eliciting intention to stay among its organizational members. According to Vandenberg and Nelson (1999), intention to stay is defined as employees' intention to stay in the present employment relationship with their current employer on a long term basis. Intention to stay in a job in the same organization or a different organization is used as a proxy for intention to stay in the organization from the employee's perspective (Agarwal \& Sajid 2017). This is an inverse concept of turnover intention or intention to quit. This aspect is increasing in its importance as the competition for talent is high and incessantly growing.

It is noteworthy that high turnover rate would result in various undesirable outcomes, particularly in terms of staffing. The most detrimental outcome of high turnover rate is productivity loss and potential loss of business opportunities, which is mainly due to assimilation process of the newly hired staff (Chew \& Chan 2008; Al-Hamdan, Manojlovich \& Tanima 2016). To rectify involuntary turnover, employers should strive to develop rigorous human resource management (HRM) initiatives, including competitive compensation and benefits package, in an effort to retain valuable employees. Besides that, employers have to ensure that employees get adequate support from other organizational members, particularly their managers and immediate supervisors. The collegiality among organizational members is deemed vital in promoting harmonious workplace relations. This would consequently elevate organizational performance through the nurturing of right behavior and attitudes among employees regardless of their positions in the organization (Chew \& Chan 2008; Mohd Zin 2017; Nancarrow et al. 2014).

Having said that, competitive salaries and benefits, incentive programs, and other reward initiatives 
should be given the highest priority by their respective employers to encourage employees to remain in their current organizations. Non-financial benefits, such as organizational, managerial, and supervisory support are of equal importance in enhancing employees' wellbeing and happiness at work. This ensures employees would stay in their current employment for a longer tenure.

\section{CONCEPTUAL BACKGROUND OF SOCIAL SUPPORT}

Social support has emerged as a prominent concept that explains an individual cognitive assessment of being reliably connected to others (Barrera 1986; Shaw \& Gant 2004). In essence, this concept, which is also conceptualized as actions taken by others in rendering assistance to a certain individual (Barrera 1986). Leavy (1983) provided a general definition of social support, which is delineated as "the availability of helping relationships and the quality of those relationships." Additionally, social support is also defined as information that leads a person to believe that he or she is cared for and loved, esteemed and a member of a network of mutual obligations (Viswesvaran, Sanchez \& Fisher 1999) whereas Shaw and Gant (2004) alternatively defined social support as how one evaluates the accessibility of social resources.

Thoits (1995) regarded social support as the coping resources that people utilize in handling stress. Specifically, the functions of social support are demonstrated by an individual's significant others, such as family members, friends, and coworkers. According to House and Kahn (1985), social support can be provided by such sources through various forms, including instrumental, informational, and emotional assistance. All of these functions are highly interdependent that form a single underlying factor labelled as social support perceived by a certain individual. In similar vein, Barrera (1986) categorized social support into structural and functional support. While most scholars focused on the functional role of social support, structural support refers to the ties that are established between organizational members, in terms of density and frequency of the network.

Carlson and Perrewe (1999) asserted that social support is an important mechanism to help alleviate stress and other negative attitudes and behaviors, be it in the work or social context. It is worthy to note that social support in the work setting may come from a range of sources, including peers and supervisors. To illustrate, supervisors who continuously provide support to their subordinates could help make the work situation less stressful. This can be done by demonstrating their willingness to help resolve employees personal problem that may have impacted their productivity at work. Supervisors also need to be flexible in dealing with employees who are facing family issues for which they have to show their full support. As for non-work-related support, this concept is of paramount importance in reducing non-work conflict. For instance, spouse support was found to be crucial in reducing workrelated conflicts among individuals at work. Evidently, social support plays a significant prognostic role in curbing negative outcomes at work as well as at home among employees.

\section{CONCEPTUAL BACKGROUND OF PAY SATISFACTION}

Pay satisfaction explains how people would respond fairly and directly to the amount of reward that they received following the services rendered. With the pay earned, they are able to purchase various forms of goods or services they desired. It is posited that the greater the reward or income they received, the higher the satisfaction level would be. In most circumstances, employees would reflect on the level of equity as commensurate to the pay they earned. For instance, they would assess their pay in terms of a standard economic benefits (Berkowitz et al. 1987). Specifically, they may assess whether the pay is equivalent to their level of contribution to the organization which is known as internal equity. Another aspect that deserves equal attention among employees is external equity, in which employees would compare their pay with employees in the same position in other organizations within the same industry.

A similar perspective on pay satisfaction has been proposed by Lawler (1971, 1981). Specifically, pay satisfaction refers to the "discrepancy between how much one feels one should receive and how much one feels is actually received." (Heneman \& Schwab 1985: 129). In other words, pay satisfaction revolves around employees' feelings of what they should receive and what they have actually received in terms of financial and non-financial reward in comparison to the service they rendered. It is also proposed that the level of pay satisfaction experienced by employees is contingent upon person factors as well as systems factor (Heneman \& Schwab 1985). The former focuses on the factors within an individual, for instance their experience and ability, while the latter centers on aspects related organizations, such as leadership, pay administration and policies.

Antecedents and outcomes related to pay satisfaction have been given sufficient scrutiny in the literature. It was reported that personal and job inputs, financial and non-financial outcomes, as well as pay policies and administration are significantly related to pay satisfaction among employees in various industries. This has been supported by Spector (1997) who reported that pay satisfaction is a significant determinant of job satisfaction.

In line with Adam's Equity Theory (1965), it is theorized that the feelings of equity within an individual is attributed to their level of pay satisfaction (Lum et al. 1998). In particular, employees would make comparison in terms of their input and output ratio. If there is a great discrepancy in terms of their contribution and pay received, they may feel that they are being underpaid. As such, the feelings of inequity may exist and this may transform into unwanted attitude and behaviors among employees, such as absenteeism, turnover, and lowered productivity and performance. 


\section{CONCEPTUAL BACKGROUND OF WORK ABILITY}

Work ability refers to workers' ability to perform their tasks and responsibilities at work (Airila et al. 2015). According to Tengland (2011), employees are considered to have work ability if they have the occupational competence, the health required for the job, and the occupational virtues that are required for executing their tasks and fulfilling their responsibilities effectively. In other words, work ability refers to the functional capacity of an employee to meet the requirements of the job assigned to him or her.

It is posited that work ability is a health-related resource that is likely to be related to employees' attitude, behavior and well-being. According to Broaden-andBuild Theory by Fredrickson (2001), there is a certain mechanism in each individual that links various factors to work ability. This theory asserts that positive emotions broaden peoples' thought action repertoires, build their enduring personal resources and consequently lead to better well-being (Airila et al. 2015; Ouweneel et al. 2012). Thus, based on the build hypotheses of the Broaden-andBuild Theory, predictors related to a certain individual or context can be assumed to build work ability.

In addition, the theory also proposes that work ability and behavior at work would mutually affect each other. This underpins the assumption that reciprocal and positive relationships exist between work ability and behaviors of individuals across different settings. This is supported by many empirical findings, Seitsamo et al. (2011) Ahlstrom et al. (2010) and Feldt et al. (2009) supported the role of work ability as a resource that may have beneficial effects on behavioral and attitudinal outcomes among individuals. It is therefore evident that work ability plays a significant role in organizational psychology research. Despite the fact that work ability is a crucial element in predicting various outcomes among individuals, research on the mediating role of work ability, particularly in the context of RTW participants, is still limited.

\section{HYPOTHESES DEVELOPMENT}

\section{SOCIAL SUPPORT AND WORK ABILITY}

The importance of social support in predicting various outcomes among individuals is well-established in the literature. According to Lin and Westcott (1991), social support is crucial in ensuring that assistance are gained from the network that a certain individual has in his or her surroundings. In parallel fashion, Wellman and Wortley (1990) agreed that the size of a person's social network, its cohesiveness, and the levels of its density of the relationships have a bearing on the type of help or assistance that a certain individual may receive from his or her social network. It is reported that social support has a substantial effect on employees' physical and mental health (Janssen et al. 2003). Importantly, social support through confidante can significantly reduce the amount of stress and anxiety that employees experience due to work overload as well as other factors. Drawing on these assertions, it is proposed that:

$\mathrm{H}_{1}$ Social support is positively related to work ability.

\section{PAY SATISFACTION AND WORK ABILITY}

Studies have reported that pay satisfaction is related to work attitude and performance (Johari et al. 2013; Wu \& Wang 2015) and turnover intention (Gieter et al. 2012; Johari et al. 2012). It is evident that pay satisfaction may have different levels of impact on employees' work attitude and behaviors. Specifically, when employees think that they are under-rewarded, they would withdraw psychologically from the situation and vice versa. This would yield to lowered performance and higher level of absenteeism and turnover rate. Based on Broaden-andBuild Theory, it is purported that positive emotions, which originate from various contextual and person factors, may broaden peoples' arrays of thoughts. This helps in generating personal resources and most importantly enhance individuals' well-being (Airila et al. 2015; Ouweneel et al. 2012). Additionally, Van den Berg et al. (2009), in their systematic review, reported that work aspects had a significant role in determining work ability among employees across different settings. Hence, the following hypothesis is proposed:

$\mathrm{H}_{2}$ Pay satisfaction is positively related to work ability.

\section{WORK ABILITY AND INTENTION TO STAY}

Traditionally, work ability is considered to be an important resource that boost health and well-being of the organizational member. Consequently, this would elicit improved work performance among employees. In accordance to Broaden-and-Build Theory by Fredrickson (2001), work ability can be viewed as a health-related resource that fosters a high level of positive energy, commitment, and motivation in one's work. Hence, it is assumed that if employees are able to perform their work effectively, they are more likely to stay in their present employment. In other words, such situation would enhance their intention to stay and hence the following hypothesis is formulated:

$\mathrm{H}_{3}$ Work ability is positively related to intention to stay.

\section{WORK ABILITY AS A MEDIATOR}

It is important to note that work ability is attributed to physiological and psychological aspects of an individual. Additionally, work ability can also be boosted through positive environment and various other contextual factors. In this vein, pay satisfaction and social support are the contextual factors that are crucial in enhancing work ability. According to Broaden-and-Build Theory by Fredrickson (2001), work ability is a health-related resource that can bring about great positive energy, high commitment, and motivation within individuals. 
Furthermore, a systematic review by Van den Berg et al. (2009) substantiated that work aspects were found to have a significant impact on employees' work ability. As a result, employees who are able to perform at their best are more likely to remain in their present employment. Drawing on the theoretical proposition and empirical evidence, it is hypothesized that:

$\mathrm{H}_{4}$ Work ability mediates the relationship between social support and intention to stay.

$\mathrm{H}_{5}$ Work ability mediates the relationship between pay satisfaction and intention to stay.

\section{UNDERLYING THEORY AND RESEARCH FRAMEWORK}

Based on the Social Exchange Theory (Cropanzano \& Mitchell 2005), it is suggested that social behavior in working environment influences individuals to respond to work responsibilities and work attitudes towards organization. Additionally, drawing on the proposition made in Broaden-and-Build Theory (Fredrickson 2001), positive situation would result in enhanced ability to perform duties and responsibilities, which in due course result in desirable outcomes. In line with this, work ability is posited to mediate the relationship between pay satisfaction, social support and intention to stay among RTW participants. As depicted in Figure 1, the model illustrates the theorized link between pay satisfaction, social support, and intention to stay.

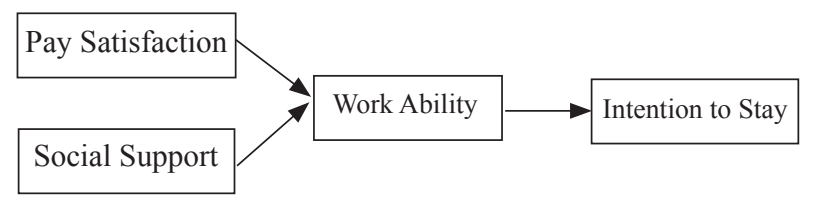

FIGURE 1. Conceptual model of the present study

\section{METHODOLOGY}

\section{RESEARCH DESIGN AND SAMPLING}

This study used a quantitative approach to examine the relationship between social support, pay satisfaction, work ability, and intention to stay. It employed a quantitative approach of purposive sampling. Study respondents were registered participants of the RTW programme. The sampling frame is available on socso database, which recorded details of the RTW participants throughout the country. This study however focused on RTW participants who were sampled in the Klang Valley area. According to the SOCSO database, the highest number of RTW participants are based in this particular geographical area. The respondents were selected based on the following criteria, namely they were registered participants of RTW, involved in any workplace accidents, representative of ethnicity and gender, and they have resumed work and are still being monitored by the case manager.
Data collection process commenced in June 2015 and ended in July 2015. Self-administered questionnaire was used to collect data on each variable understudy. Instructions were provided in the questionnaire and respondents have to answer the items based on the five point Likert scale. Sampling frame was obtained from the SOCSO database, which documented a total of 1407 participants who registered in the RTW program. According to Krejcie and Morgan (1970) sampling technique, three hundred and two (302) is a valid number of samples for this study. From the same number of questionnaires distributed, 187 responses were gathered with complete answers (a yield of 69.1\%) and this formed the basis of the study.

\section{INSTRUMENTATION AND SAMPLE ITEMS}

A total of 37 items with five-point Likert scale were used to measure all constructs understudy. The pay satisfaction instrument was adapted from Heneman and Schwab (1985). To gauge this, respondents have to indicate their level of satisfaction (i.e. 1-highly dissatisfied, 2dissatisfied, 3-moderate, 4-satisfied, and 5-highly satisfied) on 18 items, including "My current pay" and "My benefits package." Work ability was measured using seven items adapted from Zwart, Frings-Dresen and Duivenbooden (2002). Respondents had to indicate their ability to work based on the following scale i.e. 1-very poor, 2-poor, 3-fair, 4-good, and 5-very good. Sample items for this measure includes, "My current work ability compared with lifetime best" and "My work ability in relation to the demands of the job." The instrument for social support was developed by Jensen (2013), which comprised four items. To identify the amount of social support that the RTW participants experienced in their present lives, respondents had to indicate their level of agreement using the five-point Likert scale of 1-strongly disagree, 2- disagree, 3-moderate, 4- agree, and 5- strongly agree. Sample items for this measure include "I can get practical help from my family members when needed" "I can get practical help from employers when needed," and "I can get practical help from colleagues when needed." Items on intention to stay were adopted from Mowday, Koberg and McArthur (1984). Sample items comprised "If I were completely free to choose, I would prefer to keep working in this organization" and "I would like to stay at this organization for a long time."

\section{FINDINGS}

\section{DATA ANALYSIS AND RESULT}

The Statistical Package for Social Sciences and Smart PLS 2.0 Partial Least Squares Structural Equation Modelling (PLS-SEM) were used to determine and explain the reliability, validity, and relationship between the variables understudy. 
DEMOGRAPHIC PROFILE OF THE RESPONDENTS

The majority of respondents or 151 were males while their 36 female counterparts constituted only $19.3 \%$. A total of $41(31.6 \%)$ of the respondents were within the age group of 41-45 years. The majority of the respondents $(73.8 \%)$ were married, while only 27.2 were single or widowed. Most of respondents $(77.5 \%)$ indicated they were still working with the same employer while the rest have shifted to other companies. It is also important to note that $70.6 \%$ of the respondents have tertiary education (i.e. university degree or higher) and $71.7 \%$ earned more than RM2000 per month.

\section{VALIDITY AND RELIABILITY}

To ensure the measurement items were valid and reliable, data were analyzed for internal consistency (i.e., loading of each item), convergent validity, and discriminant validity. The measurement model showed that $32.3 \%$ of the variance in work ability was explained by pay satisfaction and social support. Further, only $7.8 \%$ of the variance in intention to stay was explained by work ability, pay satisfaction and social support. Table 1 depicts the factor loadings of all observed variables or items, which range from 0.466 to 0.924 .

TABLE 1 . Convergent validity

\begin{tabular}{|c|c|c|c|c|c|c|}
\hline Model construct & Measurement items & Loading/weight & $\mathrm{CR}$ & AVE & $\mathrm{R}^{2}$ & $\alpha$ \\
\hline \multirow[t]{18}{*}{ Pay satisfaction } & PS1 & 0.531 & & & & \\
\hline & PS2 & 0.637 & & & & \\
\hline & PS3 & 0.590 & & & & \\
\hline & PS4 & 0.726 & & & & \\
\hline & PS5 & 0.633 & & & & \\
\hline & PS6 & 0.719 & & & & \\
\hline & PS7 & 0.705 & & & & \\
\hline & PS8 & 0.694 & & & & \\
\hline & PS9 & 0.640 & 0.924 & 0.406 & - & 0.913 \\
\hline & PS10 & 0.646 & & & & \\
\hline & PS11 & 0.612 & & & & \\
\hline & PS12 & 0.717 & & & & \\
\hline & PS13 & 0.623 & & & & \\
\hline & PS14 & 0.566 & & & & \\
\hline & PS15 & 0.570 & & & & \\
\hline & PS16 & 0.559 & & & & \\
\hline & PS17 & 0.581 & & & & \\
\hline & PS18 & 0.669 & & & & \\
\hline \multirow[t]{4}{*}{ Social Support } & SS & 0.466 & & & & \\
\hline & $\mathrm{SS} 2$ & 0.746 & & & & \\
\hline & SS3 & 0.899 & 0.813 & 0.533 & - & 0.734 \\
\hline & SS4 & 0.742 & & & & \\
\hline \multirow[t]{7}{*}{ Work Ability } & WA1 & 0.797 & & & & \\
\hline & WA2 & 0.774 & & & & \\
\hline & WA3 & 0.728 & & & & \\
\hline & WA4 & 0.720 & 0.895 & 0.550 & 0.323 & 0.864 \\
\hline & WA5 & 0.726 & & & & \\
\hline & WA6 & 0.707 & & & & \\
\hline & WA7 & 0.732 & & & & \\
\hline \multirow[t]{3}{*}{ Intention to stay } & ITS1 & 0.766 & 0.895 & 0.741 & 0.078 & 0.829 \\
\hline & ITS2 & 0.924 & & & & \\
\hline & ITS3 & 0.884 & & & & \\
\hline
\end{tabular}

Note: $\mathrm{AVE}=$ Average variance extracted $\mathrm{CR}=$ Composite reliability; $\alpha=$ Cronbach's alpha
To measure the convergent validity of each construct's factor loadings, average variance extracted (AVE) and composite reliability (CR) were examined. According to Barclay, Higgins and Thompson (1995), the values of AVE for each construct should be greater than 0.50 . Specifically, an AVE value that is below 0.50 indicates that, on average, more error remains in the items than the variance explained by the construct (Hair et al. 2014).

As shown in Table 1, the AVE value for intention to stay, social support and work ability were higher than 0.5 . However, the AVE values for pay satisfaction (0.406) was lower than 0.5. Fornell and Larcker (1981) asserted that researchers can accept a loading value of 0.4 because the composite reliability was higher than 0.6 which means that the convergent validity of the construct is adequate. Also, to fulfill the convergent validity requirements, the $\mathrm{CR}$ for all constructs should be higher than 0.70 as suggested by Hair et al. (2010). As illustrated in Table 1, the values of CR for intention to stay, pay satisfaction, social support, work ability and intention to stay were $0.924,0.813,0.895$, and 0.895 , respectively. In addition, the Cronbach's alpha values of the variables were above 0.6 . These findings show support for validity and reliability of all measures used in the study. 
Table 2 shows the result of discriminant validity of all variables understudy. According to Fornell and Larcker (1981), to provide support for discriminant validity, the value of square root of average variance extracted (AVE) should be greater than the value of correlation coefficient of the two respective constructs. As shown in Table 2, each square root of AVE value is higher than correlation coefficients of two constructs. Therefore, the evidence of discriminant validity is supported, suggesting that there is no multicollinearity of items in representing their hypothesized latent factors. As such, it can be concluded that all measurements in this study are valid and reliable.

TABLE 2. Discriminant validity of reflective constructs

\begin{tabular}{lcccc}
\hline \multicolumn{1}{c}{ Constructs } & 1 & 2 & 3 & 4 \\
\hline 1. Pay Satisfaction & 0.637 & & & \\
2. Social Support & 0.388 & 0.730 & & \\
3. Work Ability & 0.562 & 0.298 & 0.742 & \\
4. Intention to stay & 0.336 & 0.169 & 0.279 & 0.861 \\
\hline
\end{tabular}

Note: The diagonals (in bold) represent the square root of AVE while the other entries represent the correlation coefficients.
The result indicated that pay satisfaction $(\beta=0.526, \mathrm{t}$ $=9.002, \mathrm{p}<0.01)$ and work ability $(\beta=0.279, \mathrm{t}=3.719, \mathrm{p}$ $<0.01$ ) had a significant and positive influence on intention to stay. Nevertheless, social support posed no substantial impact on work ability among RTW parcipants. Hence, $\mathrm{H}_{2}$ was rejected, but $\mathrm{H}_{1}$ and $\mathrm{H}_{3}$ supported.

\section{TEST OF HYPOTHESES: MEDIATING EFFECT}

To test whether work ability significantly mediate the relationship between pay satisfaction, social support and intention to stay, bootstrapping which is a nonparametric resampling procedure that does not impose the assumption of normality on the sampling distribution was used (Preacher $\&$ Hayes 2008). Thus, bootstrapping (500 resample) was used to generate standard errors (SE) and $t$-statistics with the percentile bootstrap $95 \%$ confidence interval. If the confidence interval for a mediation hypothesis does not contain zero, it means that the indirect effect between independent and dependent variables is supported. The bootstrapping analysis (refer to Table 4) found that work ability only mediate the influence of pay satisfaction on intention to stay. Hence, only $\mathrm{H}_{4}$ (indirect effect $=0.147$; $\mathrm{SE}=0.048 ; t$-value $=3.057)$ is supported.

TABLE 3. Direct relationship

\begin{tabular}{clccc}
\hline Hypotheses & \multicolumn{1}{c}{ Relationship } & Coefficient & t-value & Support \\
\hline $\mathrm{H}_{1}$ & Pay satisfaction $\rightarrow$ Work Ability & 0.526 & $9.002 * *$ & Yes \\
$\mathrm{H}_{2}$ & Social Support $\rightarrow$ Work Ability & 0.093 & 1.382 & No \\
$\mathrm{H}_{3}$ & Work Ability $\rightarrow$ Intention to stay & 0.279 & $3.719 * *$ & Yes \\
\hline
\end{tabular}

Note: $\mathrm{t}$ value $>2.58=$ significant at $* * \mathrm{p}<0.01$

TABLE 4. Result of hypotheses (mediating effect)

\begin{tabular}{|c|c|c|c|c|c|c|}
\hline \multirow[t]{2}{*}{ Hypotheses } & \multirow[t]{2}{*}{ Relationship } & \multirow[t]{2}{*}{ Indirect Effect } & \multirow[t]{2}{*}{$\mathrm{t}$-value } & \multicolumn{2}{|c|}{$\begin{array}{l}\text { Percentile bootstrap } \\
95 \% \text { confident interval }\end{array}$} & \multirow[t]{2}{*}{ Support } \\
\hline & & & & Lower & Upper & \\
\hline $\mathrm{H}_{4}$ & $\begin{array}{l}\text { Pay Satisfaction } \rightarrow \text { Work } \\
\text { Ability } \rightarrow \text { Intention to Stay }\end{array}$ & 0.147 & $3.057 * *$ & 0.0523 & 0.241 & Yes \\
\hline $\mathrm{H}_{5}$ & $\begin{array}{l}\text { Social Support } \rightarrow \text { Work } \\
\text { Ability } \rightarrow \text { Intention to Stay }\end{array}$ & 0.026 & 1.179 & -0.017 & 0.069 & No \\
\hline
\end{tabular}

Note: $\mathrm{t}$-value $>1.645=$ significant at $* \mathrm{p}<0.05 ; \mathrm{t}$-value $>2.58=$ significant at $* * \mathrm{p}<0.01$

\section{DISCUSSIONS}

To recapitulate, this study examined the impact of social support and pay satisfaction on intention to stay among RTW participants. It also investigated the mediating effect of work ability in the hypothesized link. The results indicated that pay satisfaction exerted a significant and positive influence on intention to stay among RTW participants. However, social support has no impact on intention to leave among respondents. Furthermore, work ability was reported to play a significant mediating role in the theorized relationship between pay satisfaction and intention to stay, but this factor did not mediate the linkage between social support and intention to stay.

The results indicated that pay satisfaction is related to work ability of RTW participants in this study and are consistent to previous findings that pay satisfaction exerted a substantial level of influence on various outcomes (see for example Wu \& Wang 2015). These are also congruent with the proposition put forward in the Broaden-and-Build Theory by Fredrickson (2001) in which work ability of an individual can be attributed to various factors that are 
within or extraneous to that particular individual. RTW participants who are happy and satisfied with the amount of pay received would develop positive emotions (Airila et al. 2015; Johari et al. 2012; Ouweneel et al. 2012). It is worthy to note that pay level before and after the accident was not significantly different for most of the respondents in the study. A great number of respondents $(77.5 \%)$ were employed by their previous employer. As such they have fully understood and satisfied with the amount of pay they received, the pay structure, and benefits offered by the employer. The state of being satisfied would consequently elicit higher work ability and hence RTW participants are able to execute their tasks and responsibilities effectively at the work place.

The findings also reported that social support failed to predict work ability among RTW participants. The results are incongruent with the findings documented by Lin and Westcott (1991) Wellman and Wortley (1990) and Taskila and Lindbohm (2007), Taskila et al. (2007) who reported that social support plays an integral part in improving work ability of employees. A plausible reason to this is due to the fact that $77.5 \%$ of the respondents are still working with their previous employers and 70.6\% have tertiary education. As such, they are already familiar with their jobs as well as the work environment they are in. Most importantly, RTW participants in the study are considered competent in their jobs given that they have adequate knowledge and related experience, which they have gathered through their tertiary education as well as their experience with the work environment and employers in their previous employment. The influence of these demographic aspects may have manifested in the relationship. In other words, these factors may plausibly influence their work ability rather than other factors, such as social support from their family members or friends.

\section{IMPLICATIONS AND CONCLUSION}

Results of the study have provided additional empirical support in the domain of Social Exchange Theory and Broaden-and-Build Theory. In terms of theoretical implications, the results validated the propositions that pay satisfaction is the key in boosting work ability among RTW participants, and this ultimately enhances their intention to stay in their present employment. Most importantly, the finding of the present study contributed empirically to the existing literature of all the domains understudied (i.e. intention to stay, pay satisfaction, and social support). As for practical ramifications, employers and the SOCSO have to exert strong emphasis on pay satisfaction element in ensuring RTW participants' work ability is enhanced and they continue to remain in their present employment. This is attributed to the fact that work ability and pay satisfaction were found to have a significant influence on intention to stay among the RTW participants.

Taken together, it is evident that the compensation and benefits package plays a tactical role in accentuating work ability while attenuating the turnover intention among employees who have undergone RTW programs. To conclude, the results of the present study have reported partial support for the key theoretical propositions, namely pay satisfaction influences work ability and eventually intention to stay among RTW participants.

\section{ACKNOWLEDGEMENT}

This research was funded by Social Security Organisation Malaysia (SOCSO), Ministry of Human Resources Malaysia.

\section{REFERENCES}

Agarwal, P. \& Sajid, S.M. 2017. A study of job satisfaction, organizational commitment and turnover intention among public and private sector employees. Journal of Management Research 17(3): 123-136.

Ahlstrom, L., Grimby-Ekman, A., Hagberg, M. \& Dellve, L. 2010. The work ability index and single-item question: Associations with sick leave, symptoms, and health - A prospective study of women on long-term sick leave. Scandinavian Journal of Work, Environment \& Health 36: 404-412.

Airilaa, A., Hakanena, J.J., Schaufeli, W.B.S., Luukkonenc, R., Punakalliod, A. \& Lusa, S. 2014. Are job and personal resources associated with work ability 10 years later? The mediating role of work engagement. Work \& Stress: An International Journal of Work, Health \& Organisations 28(1): 87-105.

Al-Hamdan, Z., Manojlovich, M. \& Tanima, B. 2016. Jordanian nursing work environments, intent to stay, and job satisfaction. Journal of Nursing Scholarship 49(1): 103110 .

Awang, H., Mansor, N. \& Rodrigo, S.K. 2015. Work related injury and illness: Exploring the return-to-work program in Malaysia. Southeast Asian Journal of Tropical Medicine and Public Health 46(6): 1124-1133.

Awang, H., Shahabudin, S.M. \& Mansor, N. 2016. Return-toWork program for injured workers factors of successful return to employment. Asia-Pacific Journal of Public Health 28(8): 694-702.

Barclay, D.W., Higgins, C.A. \& Thompson, R. 1995. The partial least squares approach to causal modeling: Personal computer adoption and use as illustration. Technology Studies 2: 285-309.

Barrera, M. 1986. Distinctions between social support concepts, measures, and models. American Journal of Community Psychology 14(4): 413-445.

Berkowitz, L., Cochran, S., Fraser, C. \& Treasure, F.P. 1987. Pay, equity, job gratifications, and comparisons in pay satisfaction. Journal of Applied Psychology 72(4): 544551.

Carlson, D.S. \& Perrewe, P.L. 1999. The role of social support in the stressor-strain relationship: An examination of workfamily conflict. Journal of Management 25(4): 513-540.

Chew, J. \& Chan, C. A. 2008. Human resource practices, organizational commitment and intention to stay. International Journal of Manpower 29(6): 503-522. 
Cropanzano, R. \& Mitchell, M.S. 2005. Social Exchange Theory: An interdisciplinary review. Journal of Management 31(6): 874-900

EARN (Employer Assistance and Resource Network on Disability Inclusion). 2018. Stay at Work/Return to Work. Available at http://www.askearn.org/topics/retentionadvancement/stay-at-work-return-to-work/ .

Feldt, T., Hyvönen, K., Mäkikangas, A., Kinnunen, U. \& Kokko, K. 2009. Development trajectories of Finnish managers work ability over a 10-year follow-up period. Scandinavian Journal of Work, Environment \& Health 35: 37-47.

Fornell, C. \& Larcker, D.F. 1981. Evaluating structural equation models with unobservable variables and measurement error Journal of Marketing Research 18(1): 39-50.

Fredrickson, B.L. 2001. The role of positive emotions in positive psychology. The broaden and-build theory of positive emotions. American Psychologist 56: 218-226.

Gieter, S.D., Cooman, R.D., Hofmans, J., Pepermans, R. \& Jegers, M. 2012. Pay-level satisfaction and psychological reward satisfaction as mediators of the organizational justice-turnover intention relationship. International Studies of Management and Organization 42(1): 50-67.

Hair, J.F., Black, W.C., Babin, B.J. \& Anderson, R.E. 2010. Multivariate Data Analysis. Upper Saddle River, New Jersey: Prentice Hall.

Hair, J.F., Hult, G.T.M., Ringle, C.M. \& Sarstedt, M. 2014. A Primer on Partial Least Squares Structural Equation Modeling (PLS-SEM). Thousand Oaks: Sage.

Heneman, H.G. \& Schwab, D.P. 1985. Pay satisfaction: Its multidimensional nature and measurement. International Journal of Psychology 20(1): 129-141.

House, J.S. \& Kahn, R.L. 1985. Measures and concepts of social support. In Social Support and Health, edited by S. Cohen \& S. L. Syme, 83-108. Orlando, FL: Academic Press

Janssen, N., van de Heuvel, W.P., Beurskens, A.J., Nijhuis, F.J., Schroer, C.A. \& van Eijk, J.T. 2003. The demand-control support model as a predictor of return to work. International Journal of Rehabilitation Research 26: 1-9.

Jensen, A.G.C. 2013. Towards a parsimonious program theory of return to work intervention. IOS Press 44: 155-164.

Jetha, A., Pransky, G., Fish, J. \& Hettinger, L.J. 2016. Return-toWork within a complex and dynamic organizational work disability system. Journal of Occupational Rehabilitation 26(3): 276-285

Johari, J., Yean, T., Adnan, Z., Yahya, K.K. \& Ahmad, M.N. 2012. Promoting employee intention to stay: Do human resource management practices matter? International Journal Economics and Management 6(2): 396-416.

Johari, J., Adnan, Z., Yean, T.F., Yahya, K.K. \& Isa, S.N. 2013. Fostering employee engagement through human resource practices: A case of manufacturing firms in Malaysia. Jurnal Pengurusan 38(1): 15-26.

Krejcie, R.V. \& Morgan, D.W. 1970. Determining sample size for research activities. Educational and Psychological Measurement 30(3): 607-610.

Lawler, E.E. 1971. Pay and Organizational Effectiveness. New York, NY: McGraw Hill.

Lawler, E.E. 1981. Pay and Organizational Effectiveness. Reading, MA: Addison-Weslye.

Leavy, R.L. 1983. Social support and psychological disorder: A review. Journal of Community and Psychology 11: 3-21.

Lum, L., Kervin, J., Clark, K., Reid, F. \& Sirola, W. 1998. Explaining nursing turnover intent: Job satisfaction, pay satisfaction, or organizational commitment. Journal of Organizational Behavior 19(3): 305-320.

Lin, N. \& Westcott, J. 1991. Marital engagement/disengagement, social networks, and mental health. In The Social Context of Coping, edited by J. Eckenrode, 213-237. New York: Plenum.

Mohd Zin, M.L. 2017. The mediating role of perceived organizational support on the relationship between pay and intention to stay. Management Review: An International Journal 12(1): 57-76.

Mowday, R.T., Koberg, C.S. \& McArthur, A.W. 1984. The psychology of the withdrawal process: A cross-validation test of Mobley's intermediate linkages Model of turnover in two samples. Academy of Management Journal 27(1): 79-94.

Nancarrow, S., Bradbury, J., Winona, S. \& Ariss, S. 2014. Intention to stay and intention to leave: Are they two sides of the same coin? A cross-sectional structural equation modelling study among health and social care workers. Journal of Occupational Health 56: 292-300.

Ouweneel, E., Le Blanc, P., Schaufeli, W.B. \& Van Wijhe, C. 2012. Good morning, good day: A diary study on positive emotions, hope, and work engagement. Human Relations 65: 1129-1154.

Preacher, K.J. \& Hayes, A.F. 2008. Asymptotic and resampling strategies for assessing and comparing indirect effects in simple and multiple mediator models. Behavior Research Method 40: 879-891.

Seitsamo, J., von Bonsdorff, M. E., Ilmarinen, J., von Bonsdorff, M. B., Nygård, C.-H., Rantanen, T. \& Klockars, M. 2011. Work ability and later-life health: A 28-year longitudinal study among Finnish municipal workers. In Age Management during the Life Course. Proceedings of the 4th Symposium On Work Ability, edited by C.H. Nygård, M. Savinainen, T. Kirsi \& K. Lumme-Sandt, 391-398. Tampere: Tampere University Press.

SOCSO. 2015. Social Security Organization Annual Report. Available at www.perkeso.gov.my.

SOCSO. 2016. Social Security Organization Annual Report. Available at www.perkeso.gov.my.

Shaw, L.H. \& Gant L.M. 2004. In defense of the internet: The relationship between internet communication and depression, loneliness, self-esteem, and perceived social support. Cyber Psychology and Behavior 5(2): 157-171.

Spector, P.E. 1997. Job Satisfaction: Application, Assessment, Causes, and Consequences. Thousand Oaks, CA: Sage.

Steenstra, I.A., Munhall, C., Irvin, E., Oranye, N., Passmore, S., Van Eerd, D., Mahood, Q. \& Hogg-Johnson, S. 2016. Systematic review of prognostic factors for return to work in workers with subacute and chronic low back pain. Journal of Occupational Rehabilitation 27(3): 369-381.

Taskila, T. \& Lindbohm, M.L. 2007. Factors affecting cancer survivors' employment and work ability. Acta Oncologica 46(4): 446-451.

Taskila, T., Martikainen, R., Hietanen, P. \& Lindbohm, M.L. 2007. Comparative study of work ability between cancer survivors and their referents. European Journal of Cancer 43(5): 914-920.

Tengland, P.A. 2011. The concept of work ability. Journal of Occupational Rehabilitation 21: 275-285.

Thoits, P.A. 1995. Stress, coping, and social support processes: Where are we? What next? Journal of Health and Social Behavior 35 (Extra Issue): 53-79. 
Vandenberg, R.J. \& Nelson J.B. 1999. Disaggregating the motives underlying turnover intentions: When do intentions predict turnover behavior? Human Relations 52(10): 1313-1336.

Van den Berg, T.I.J., Elders, L.A.M., Zwart, B.C.H. \& Burdorf, A 2009. The effects of work related and individual factors on the work ability index: A systematic review. Occupational and Environmental Medicine 66: 211-220.

Viswesvaran, C., Sanchez, J.I. \& Fisher, J. 1999. The role of social support in the process of work stress: A meta-analysis. Journal of Vocational Behavior 54: 314-334.

Wellman, B. \& Wortley, S. 1990. Different strokes from different folks: Community ties and social support. American Journal of Sociology 96(3): 558-588.

Wu, X. \& Wang, C. 2008. The impact of organizational justice on employees' pay satisfaction, work attitudes, and performance in Chinese hotels. Journal of Human Resources in Hospitality and Tourism 7(2): 181-195.

Yean, T.F., Johari, J. \& Sukery, A. F. 2015. The influence of attitude, subjective norms, and perceived behavioural control on intention to return to work: A case of SOCSO's insured employees. Kajian Malaysia 33(1): 141-154

Johanim Johari (corresponding author)

School of Business Management

Universiti Utara Malaysia

06010 UUM Sintok, Kedah, MALAYSIA.

E-Mail: johanim@uum.edu.my
Fatimah Zailly Ahmad Ramli

School of Applied Psychology, Social Work and Policy

Universiti Utara Malaysia

06010 UUM Sintok, Kedah, MALAYSIA.

E-Mail: zailly@uum.edu.my

Harlida Abdul Wahab

School of Law

Universiti Utara Malaysia

06010 UUM Sintok, Kedah, MALAYSIA.

E-Mail: harlida@uum.edu.my

Muhammad Firdaus Bidin

School of Law

Universiti Utara Malaysia

06010 UUM Sintok, Kedah, MALAYSIA.

E-Mail: firdausbidin@uum.edu.my

Roshaimi Mat Rosely

Social Security Organisation

Ministry of Human Resources Malaysia

Menara Perkeso, 281 Jalan Ampang

50538 Kuala Lumpur, MALAYSIA

E-Mail: roshaimi.rosely@perkeso.gov.my 